\title{
Rio+20 og Afrika
}

\section{Geert Aagaard Andersen $\mathcal{E}$ Asger Hallberg Borg}

Rio+20 var starten på en proces, som kan være med til at gøre verden til et bedre sted. Opfølgningen vil vise, om det også kommer til at gælde for Afrika

Forventningerne til FN's konference for bæredygtig udvikling i Rio de Janeiro, Rio+20, i slutningen af juni var fra alle sider store. Omfattende ressourcer var sat ind for at sikre et positivt resultat. Og de historiske referencer til det berømmede verdenstopmøde i 1992 var med til at skrue forventningerne i vejret.

Rio+20 er ofte blevet omtalt som en konference om miljøet. Det var Rio+20 også, men det var først og fremmest en konference om en ny fælles udviklingsdagsorden. Om et skifte bort fra en udvikling, hvor en kompleks blanding af markedsfejl, ødelæggende politiske beslutninger og institutionelle mangler har bidraget til, at jordens ressourcer bruges ineffektivt og medfører et kolossalt ressourcespild.

En udvikling, der ikke har taget hensyn til omkostningerne ved nedslidning af jordens ydeevne, reduktion af vandressourcer og skovom- råder, $\mathrm{CO}_{2}$-forurening og en voldsom overudnyttelse af havets ressourcer. En udvikling, hvor verdens fattige lande, som de mest sårbare og med de ringeste muligheder for at påvirke de globale trends, i stigende grad er og forbliver taberne.

De afrikanske lande kunne derfor slutte op om Rio-konferencens mål om en fælles dagsorden for et udviklingsparadigme, hvor økonomiske, sociale og miljømæssige hensyn samtænkes med det mål at sikre en bæredygtig udvikling, der begunstiget af effektive internationale institutionelle rammer, bidrager til fattigdomsbekæmpelse. Af samme grund var der store forhåbninger til konferencen blandt de afrikanske lande, som nok har haft pæne vækstrater de senere år, men hvor fattigdom, klimaforandringer og nedbrydning af naturressourcegrundlaget hver for sig og tilsammen udgør en enorm udfordring for sikrin- 
gen af en bæredygtig udvikling.

Med begrænsede ressourcer på såvel det tekniske som finansielle område kan de afrikanske lande ikke løfte opgaven alene, og Rio+20 var derfor imødeset som en mulighed for at skabe opmærksomhed omkring kontinentets udfordringer og - ikke mindst - sikre teknisk og finansiel støtte til at adressere dem.

Resultatet af Rio+20 blev dokumentet The future we want. 53 sider med 283 knastørre paragraffer. Var det, hvad afrikanerne var kommet efter?

\section{Fejlslagen udvikling}

Gennem de sidste 20 års økonomiske vækst er mere end 600 millioner mennesker løftet ud af fattigdom. En vækst, der har bragt økonomisk og social fremgang for yderligere millioner af mennesker, men som samtidig har haft en markant og negativ indflydelse på miljøet. Medens væksten særligt har fremmet udviklingen for millioner af asiater og latinamerikanere, har de negative virkninger på miljøet været globale og truer fortsatte fremskridt i verdens fattigste lande og især i Afrika.

Med den fortsat stigende udledning af $\mathrm{CO}_{2}$ bliver truslen mod jordens klima i kraft af temperaturstigninger stadig større. Ørkendannelse, øget risiko for hedebølger, hyppigere og kraftigere nedbørsperioder vil sammen med havvandsstigninger dramatisk ændre livsbeting- elserne i mange områder af verden. En udvikling der i mange lande har været stimuleret af subsidier i produktion af såvel fødevarer som fossile brændstoffer.

Ekstensivt landbrug og fattigdomsbetinget subsistenslandbrug har samtidig bidraget til udpining af jorden og afskovning. I perioden 20002010 har afskovning medført, at klodens skovareal er blevet reduceret med 5,2 millioner hektar årligt hovedsagelig i tropiske egne, hvor artsvarieteten samtidig er blevet påvirket negativt. I 2008 var 25 pct. af jordens landområder påvirket af jorderosion, forøget saltindhold, udpining af næringsstoffer og ørkendannelse.

På trods af økonomisk fremgang er fattigdommen forsat omfattende. Globalt er 1,3 milliarder mennesker stadig uden adgang til elektricitet, 2,6 milliarder uden adgang til sanitære faciliteter, og 900 millioner mennesker er uden adgang til rent drikkevand. Vandindvinding er tredoblet i de seneste 50 år, og 80 pct. af jordens befolkning er nu bosat $i$ områder, hvor adgangen til rent drikkevand er truet.

Medens miljøændringerne er globale, er effekterne heraf mest mærkbare for befolkningerne i de fattigste lande, hvor modstandskraften over for tørkeperioder og oversvømmelser er begrænset og sårbarheden dermed størst. Den økonomiske vækst i de afrikanske lande er de seneste ti år kommet op i gear, men 
det økonomiske råderum er utilstrækkeligt i forhold til de enorme sociale og miljømæssige udfordringer, kontinentet står overfor.

\section{Et institutionelt spindelvæv}

De afrikanske lande ser ligesom andre udviklingslande det internationale samfund som en mulighed for at opnå såvel teknisk som finansiel støtte til at imødegå truslerne mod vækst og social fremgang.

Siden FN-topmødet i Stockholm i 1972, hvor 119 lande samledes om at etablere FN's miljøprogram (UNEP), har det internationale samfund opbygget et meget omfattende og komplekst system til at fremme et bedre miljø og støtte udviklingslandenes bestræbelser på at imødegå de miljømæssige udfordringer.

Systemet er tredelt. For det første skal UNEP som det internationale samfunds centrale miljøorganisation følge udviklingen på miljøområdet og fremkomme med videnskabeligt begrundede anbefalinger til nye adfærdsregulerende normer. Andre organisationer uden for FN bidrager hertil.

For det andet bidrager FN's udviklingsprogram, UNDP, sammen med andre FN-organisationer til gennemførelsen af miljø- og udviklingsprojekter, hovedsageligt i de fattigste lande, og med teknisk støtte.

Endelig yder Global Environment Facility (GEF), der blev etableret som finansieringsinstitution for Rio- konventionerne (klima, biodiversitet og ørken), sammen med store internationale finansieringsinstitutioner som Verdensbanken, regionale udviklingsbanker samt bilaterale donorer og NGO'er teknisk og især finansiel støtte til miljøområdet.

Siden 1972 er dette internationale forvaltningsapparat vokset. Særligt i årene efter Rio-topmødet i 1992 skete der en voldsom vækst. Nye internationale og regionale aftaler blev indgået, og til næsten hver ny aftale etableredes nye styrende organer med egne internationale sekretariater og budgetter. Men ligesom de indgåede aftaler ofte har indeholdt uklare politiske kompromiser, har de medfølgende sekretariater i mange tilfælde uklare og overlappende mandater, og finansieringen har været utilstrækkelig. De senere års økonomiske udvikling, hvor mange udviklingslande nu overgår europæiske og andre vestlige landes økonomiske formåen, har ikke grundlæggende ændret forhandlingsstrukturerne i miljøforhandlingerne. Gruppen af $77 \mathrm{og}$ Kina (G77) er stadig udviklingslandenes forhandlingsblok. Et forhold der på flere områder - ikke mindst på spørgsmål om byrdefordeling har vanskeliggjort forhandlingerne. For mange udviklingslande er alternativet til at støtte op om G77 imidlertid ikke politisk gangbart.

Det er med andre ord lykkedes at etablere et uhyre komplekst internationalt miljøregelsæt med dertilhø- 
rende forvaltningsstrukturer og rapporteringsforpligtelser, der for de fleste lande er uoverskueligt. Det har medført, at de begrænsede midler generelt er blevet spredt meget tyndt og dermed har været utilstrækkelige til at sikre en effektiv gennemførelse af de indgåede aftaler. Man kunne med et citat fra en tidligere dansk LO-formand konstatere om udviklingen i den internationale miljøforvaltning, at "man har sejret ad helvede til”.

På grund af systemets mangfoldighed og kompleksitet og forhandlingernes ofte høje krav til specifik teknisk kunnen har langt de fleste udviklingslande ikke ressourcer til at engagere sig i forhandlingerne. Alene de 10 væsentligste globale miljøaftaler har således tilsammen langt over 400 mødedage årligt. Risikoen for at blive kørt over er betydelig, og fristelsen til at blokere forhandlingerne - bare for at være på den sikre side - er stor.

Målet med Rio+20 var derfor ikke blot et skifte hen imod de mere effektive og bæredygtige produktionsog forbrugsformer, der ligger i den grønne økonomi. Det var også etableringen af et internationalt rammeværk, som effektivt understøtter en bæredygtig udvikling.

\section{Afrikas grønne omstilling}

Da Sydafrikas vand- og miljøminister i februar 2012 skulle redegøre for sit syn på grøn økonomi, var beskeden klar: "Grøn økonomi er ikke noget nyt for afrikanske lande. Vi har måske kaldt det noget andet indtil nu, men omstillingen til grønne $\varnothing$ konomier er allerede i fuld gang i Afrika." På et kontinent, hvor landbrugsproduktion udgør levebrødet for 65 pct. af befolkningen og bidrager med 32 pct. af kontinentets samlede BNP, kombineret med voksende omkostninger til import af fossile brændstoffer og stærkt svingende priser på traditionelle fødevarer, er bæredygtig forvaltning og udnyttelse af naturressourcer således blevet stadig mere attraktivt.

Reduktion i anvendelsen af fossile brændstoffer og vand, reduktion af spildet fra fødevareproduktion, mere hensigtsmæssig anvendelse af gødningsstoffer og sprøjtegifte, øget fokus på lukrative eksportmarkeder og voksende beskæftigelse. Det er grøn økonomi for et voksende antal afrikanske lande.

Latinamerikanske spekulationer om, at grøn økonomi skulle være et vestligt redskab til at opstille handelshindringer for udviklingslandene, vækker derfor ikke genklang i landene syd for Sahara.

En række afrikanske lande har allerede vedtaget lovgivning, strategier og handlingsplaner for, hvordan omstilling til grøn økonomi kan bruges som redskab til fattigdomsbekæmpelse og økonomisk og social udvikling. Rwanda har iværksat en omfattende plan for bæredygtig naturressourceforvaltning og en 
genopretningsplan for økosystemer, som sammen med den overordnede nationale strategi for klima og grøn vækst skal bidrage til at indfri målsætningen om at opnå status som middelindkomstland inden 2020.

Der er stribevis af andre konkrete eksempler. I Uganda har man over en årrække arbejdet på at fremme $ø$ kologisk landbrugsproduktion gennem rådgivning, certificering og forbedring af bønders markedsadgang. Alt sammen til gavn for bøndernes indtjening, landets eksport og naturligvis miljøet. Tilsvarende tilskynder Kenyas energipolitik gennem garanterede høje afregningspriser på vedvarende energi energiproducenter til at investere i grønne teknologier. Og i Ghana har udfasningen af subsidier til fossile brændstoffer frigjort ressourcer til udbygning af offentlig transport og øget adgang til uddannelses- og sundhedsydelser.

Men også lokale initiativer gør en forskel og bidrager til omstillingen. I Kenya har etableringen af en mangoforarbejdningsfabrik i kystbyen Malindi kombineret med rådgivning om bedre dyrkningsmetoder medført, at der er skabt 40 nye arbejdspladser, ligesom bønderne nu får op til tre gange mere for mangohøsten. Hvor 40-60 pct. af mangoerne tidligere rådnede, inden de nåede fabrikken, forarbejdes og pakkes de nu umiddelbart efter høsten, og affaldsprodukter genanvendes til gødning. Projektet er blevet til med støtte fra Danida, og lignende projekter sigter mod at effektivisere den vigtige landbrugssektor.

Initiativer som disse skubber alle i den rigtige retning. Men hverken $\varnothing$ kologiske landbrug eller mangofabrikker gør det alene. Fattigdommen er Afrikas største problem. 47 pct. af befolkningen syd for Sahara lever stadig for mindre end 1,25 dollar om dagen. På trods af et fald i såvel den absolutte som relative fattigdom, vil 2015-målene om en halvering af fattigdommen ikke kunne nås i Afrika.

Produktionsstrukturerne og incitamenter i såvel produktion som forbrug må tilpasses den grønne økonomi, og der er behov for omfattende investeringer, hvis effekten på beskæftigelse og indkomst skal slå igennem på nationalt plan. Afrika har hverken ressourcer, teknologi eller know-how til at gøre det selv. Med det budskab rejste de afrikanske delegationer til Rio.

\section{Uindfriede løfter}

Forberedelserne til Rio+20 var grundige, og de afrikanske lande havde gjort sig store bestræbelser på at enes om en fælles position og tale med én stemme. Lokale høringsprocesser og nationale analyser havde klarlagt prioriteterne, og i oktober 2011 enedes først afrikanske ministre og siden statsoverhoveder om de afrikanske positioner.

Klimaændringer, voksende vand- 
mangel, ødelæggelse af økosystemer, ørkenspredning og høj grad af sårbarhed over for naturkatastrofer blev anerkendt ikke blot som udfordringer, men også som muligheder for at fremme omstillingen til grønne økonomier.

Bæredygtig anvendelse af jord, muligheden for at sammenkoble industriudvikling med bæredygtigt forbrug af ressourcer, bedre sammenhæng mellem videnskab og produktion, og behovet for investeringer og overførsel af teknologi og teknisk viden, blev understreget som midler til denne omstillingsproces. Redskabet hertil lå i et reformeret internationalt miljøforvaltningssystem. Først og fremmest gennem en styrkelse af UNEP, som har hovedkvarter i Kenyas hovedstad Nairobi.

UNEP's rådgivning inden for miljøspørgsmål er meget efterspurgt i de afrikanske lande, og UNEP nyder anerkendelse for indsatsen. Men UNEP's budget er begrænset og baseret på frivillige bidrag, så i mange tilfælde kan ønsket om rådgivning ikke imødekommes. UNEP's styrende organ er endvidere kontrolleret af FN i New York, og organisationen mangler generelt gennemslagskraft.

Derfor var de afrikanske lande enige om at give UNEP et styrket mandat og handlekraft i og uden for FN-systemet, øget politisk synlighed, øgede ressourcer og dermed forbedrede muligheder for at bistå de afrikanske lande med kapacitets- opbygning. UNEP skulle kort sagt opgraderes til FN-særorganisation på linje med WHO, FAO og ILO. Men hovedbudskabet i den afrikanske position var, at kontinentet havde gjort betydelige fremskridt i retning af bæredygtig udvikling siden 1992. Og skulle den positive udvikling fortsætte, var der brug for hjælp udefra.

Det internationale samfund skulle derfor først og fremmest leve op til forpligtelser om økonomisk støtte, og overførsel af viden og teknologiske løsninger. Det over 40 år gamle løfte fra de udviklede lande om at anvende mindst 0,7 pct. af BNP til udviklingsbistand er således langt fra at blive nået, idet kun fire lande (heriblandt Danmark) lever op til målsætningen.

\section{Blandt ligesindede?}

Selvom de afrikanske forhandlingspositioner forud for Rio+20 på flere områder lå tættere på EU's, lykkedes det hardlinere at skabe intern enighed i den afrikanske delegation om at arbejde inden for rammerne af G77.

G77 holdt derfor - trods indbyrdes uenighed - sammen til det sidste punktum var sat. Dermed kom den afrikanske dagsorden til at stå i skyggen af den traditionelle konflikt mellem de vestlige lande og G77landene, anført af især hardlinere og ressourcestærke udviklingslande, der kun anerkender grøn økonomi 
på et overordnet plan og ikke ønsker internationale regler for gennemførelsen heraf. Der er typisk tale om middelindkomstlande, som ikke har brug for UNEP, og som ser internationale standarder og normdannelse som omkostningsfuld indblanding i interne anliggender.

Midt i en international økonomisk krise, med en meget presset euro og en række europæiske lande med behov for at anvende ledige midler på andet end udviklingsbistand, var der ikke lagt op til, at udviklingslandene ville kunne få nye ressourcer stillet til rådighed til gennemførelse af grøn økonomi. Det var imidlertid holdningen i G77, at hvis man ikke kunne blive enig om finansiering i Rio, hvornår skulle man så blive det?

Den afrikanske gruppe stod klar i kulissen med en mere konstruktiv og forsonlig tilgang. Men enigheden og sammenholdet i G77 blev fastholdt. At G77 endte med at give de nødvendige indrømmelser, der bidrog til en aftale, kan dog i en vis udstrækning tilskrives de mildere afrikanske vinde. Muligheden for at alliere sig med eksempelvis EU blev imidlertid ikke udnyttet.

"Man kan ikke få alt, hvad man peger på." Således opsummerede en af de stærkeste afrikanske fortalere for den grønne økonomi, Congos minister for bæredygtig udvikling, Henri Djombo, resultatet i Rio. En deltager i den kenyanske delegation karakteriserede slutdokumentet som et balanceret kompromis, som ikke trådte Afrika over tæerne, og som man fra afrikansk side kunne være rimelig tilfreds med. Følgende kan fremhæves:

Der blev enighed om at iværksætte processer, som skal munde ud i en finansieringsstrategi for bæredygtig udvikling og en mekanisme for teknologioverførsel. De afrikanske lande havde gerne set egentlige og nye forpligtelser fra de udviklede lande, men udsigten til støtte - og gentagelse af tilsagnet fra de udviklede lande om at bidrage med 0,7 pct. af BNP til udviklingsbistand - blev situationen taget i betragtning anset som tilfredsstillende.

UNEP blev ikke opgraderet til en særorganisation for miljøet, men især to beslutninger kan vise sig at give organisationen øget indflydelse. Der er enighed om, at UNEP's styrelsesråd skal have universelt medlemskab. Det betyder, at alle landes miljøministre fremover vil have en stemme i beslutninger, der vedrører UNEP's arbejde. Det styrker UNEP's autoritet og legitimitet og bidrager til større engagement fra FN-medlemslandene.

For det andet skal UNEP's ressourcegrundlag øges. De afrikanske lande får dermed bedre muligheder for adgang til rådgivning og teknisk støtte. Og Nairobi styrkes som centrum for det internationale samfunds væsentligste aktør på miljøområdet. Også det har betydning.

En afrikansk bekymring retter sig 
mod beslutningen om at etablere et internationalt forum for bæredygtig udvikling. Som det ses fra afrikansk side, vil dette forum kunne reducere UNEP's tiltænkte rolle som koordinator for FN's arbejde på miljøområdet og som dagsordensættende for internationale miljøspørgsmål.

Omend de afrikanske lande gerne havde set mere en forpligtende tekst om grøn økonomi - og midler til finansiering heraf - er der tilfredshed med, at omstillingen til grøn økonomi skal tage udgangspunkt i nationale politikker og strategier.

Beslutningen om, at udarbejdelse af globale bæredygtighedsmål skal finde sted i en nyoprettet komite i FN-regi, har også afrikansk støtte. Fra afrikansk side har ønsket været, at nye mål ikke fjerner fokus fra 2015-målene.

Generelt har de afrikanske lande været tilfredse med 2015-målene, som med deres fokus på fattigdom og social udvikling i høj grad er orienteret omkring Afrikas udfordringer, og er nyttige som finansieringsredskab.

Afrikansk opbakning til nye målsætninger for bæredygtig udvikling vil derfor i sidste ende afhænge af, at fattigdomsbekæmpelse ikke overskygges af hensynet til miljø og bæredygtighed. Fattigdomsbekæmpelse vil være i fokus for de afrikanske lande i mange år fremover.

\section{Så vidt så godt}

Rio+20-slutdokumentet er blevet kritiseret i skarpe vendinger af såvel topmødedeltagere som -iagttagere.

Som flere imidlertid også har mindet om, så fik Rio-topmødet i 1992 heller ikke mange rosende ord med på vejen i dagene efter, at stats- og regeringscheferne havde forladt forhandlingsbordene. Men i dag sættes der næppe mange steder spørgsmålstegn ved topmødets betydning for den kollektive forståelse af bæredygtig udvikling.

Det er i det lys, Rio+20 skal vurderes - som starten på en proces, hvor resultaterne vil vise sig i de kommende år. I første omgang flyttes forhandlingerne til FN's Generalforsamling. Her skal de afrikanske lande forsøge at holde fast i slutdokumentets positive elementer. Hertil kan de vente europæisk støtte. Som miljøminister Ida Auken udtalte, så var slutdokumentet "ikke verdens bedste tekst, men det kan være med til at gøre verden til et bedre sted."

Opfølgningen på beslutningerne i Rio vil vise, om det også kommer til at gælde for Afrika.

Geert Aagaard Andersen er cand.oecon. og Danmarks ambassadør $i$ Kenya. Asger Hallberg Borg er cand.scient.soc. og ansat ved ambassaden $i$ Nairobi. 